\title{
ZDÔVODNENIE LUDSKÝCH PRÁV V KONCEPCII EFEKTÍVNEHO ALTRUIZMU
}

MARTIN FOLTIN, Filozofický ústav Slovenskej akadémie vied, Bratislava, SR

FOLTIN, M.: Reasoning of Human Rights in the Concept of Effective Altruism FILOZOFIA, 74, 2019, No 8, pp. $622-636$

\begin{abstract}
The paper deals with the normative reasoning of human rights in the concept of effective altruism. It focuses on the analysis of the works of Peter Singer and Thomas W. Pogge, who argue in favor of the moral obligation to protect human rights of people living in extreme poverty. The aim of the paper is to introduce the main principles of the universal and perfectionist-utilitarianist perspective of Peter Singer, the political understanding of protection of human rights by Thomas Pogge and the idealized ethical concept of effective altruism. In the article we say that normative philosophical reasonings are not sufficient to justify the protection of human rights and that they are only one of many alternatives to their reasoning.
\end{abstract}

Keywords: Human rights - Effective altruism - Consequentialism - Singer, P. Reasoning of human rights - Pogge, Th. - Poverty - Global justice

\section{Úvod}

V štúdii sa zaoberáme normatívnym zdôvodnením l'udských práv v koncepcii efektívneho altruizmu. ${ }^{1} \mathrm{~V}$ prvej časti sa zameriavame na hlavné normatívne zdôvodnenia Petra Singera, ktoré obsahujú univerzálno-utilitaristické predpoklady. Jeho morálno-kozmopolitný pohl'ad rozširujeme o inštitucionálno-politickú perspektívu Thomasa Poggeho. V štúdii vychádzame z hypotézy, že tieto morálno-kozmopolitné a inštitucionálnopolitické pohl'ady sú charakteristické pre súčasný efektívny altruizmus, pretože sú jedným z pilierov, ktoré podporujú snahu altruistických subjektov, aby zvážili, akým spôsobom využívajú zdroje či akú z altruistických možností je správne vybrat'. Filozofia má pri tomto zdôvodňovaní dôležitý význam. Jej priestor vidíme v kritickom pristupovaní k tomu, ako sa využívajú filozofické normatívne zdôvodnenia na určenie explicitných a implicitných princípov normatívnych hodnôt, preferencií, metodík či politicko-inštitucionálnych úsudkov. To je aj dôvod, prečo sa pokúsime ukázat', že efektívny altruizmus

\footnotetext{
${ }^{1}$ Cenné a kritické pripomienky anonymných recenzentov časopisu Filozofia vo vel'kej miere prispeli k objasneniu našich stanovísk, za čo im patrí aj srdečná vd’aka.
} 
sa nesnaží len reformovat' spôsob altruistického správania, ale aj medzinárodné politické inštitúcie, ktoré podporujú západné krajiny, čím sa zamýšl’ame nad tým, či efektívni altruisti obhajujú pozitívnu alebo negatívnu morálnu povinnost'.

Ďalším cielom tejto štúdie je objasnit' vybrané nedostatky súvisiace s ideou ludských práv v koncepcii efektívneho altruizmu. V tomto zmysle obhajujeme tézu, že transformácia morálnych základov, ako vyplýva z morálno-kozmopolitnej obhajoby l'udských práv, je prakticky nemožná, pretože normatívne zdôvodnenia nemožno redukovat' na fakty a že individuálna transformácia našej morálky môže byt' v priamom rozpore so spoločenskými normami a inštitucionálnymi pravidlami. V poslednej časti argumentujeme, že morálne a politické normatívne zdôvodnenia l'udských práv nie sú postačujúce na ich zdôvodnenie, pretože neberú do úvahy právnu normatívnost' l'udských práv.

\section{Základné idey efektívneho altruizmu}

Filozofické východiská efektívneho altruizmu možno doložit' na základe eseje Petra Singera z roku 1972, v ktorej tvrdil, že obyvatelia bohatých krajín majú povinnost' pomáhat' chudobným obyvatel'om v rozvojových krajinách. Jeho argumentácia pozostávala $\mathrm{z}$ troch premís:

Premisa 1: Utrpenie a smrt' sú zlé. (Singer nepredpokladá, že túto premisu by sme mohli nejako spochybnit');

Premisa 2: Ak je v našich silách zabránit' niečomu, čo je zlé, bez toho, aby sme obetovali čokol'vek, čo môže mat' porovnatel'ne morálny význam, z morálneho hl'adiska by sme to mali vykonat' (tzv. princíp obetovania sa - Principle of Sacrifice ${ }^{2}$ );

Premisa 3: Je v našej moci, aby sme zabránili utrpeniu, ktoré prežívajú chudobní, a to darovaním do jednej z charít.

Záver: Máme morálnu povinnost' zamedzit' utrpeniu a umieraniu chudobných, a to darovaním finančných prostriedkov charite (Singer, 1972, 231 -232).

V štúdii sa zameriavame prioritne na druhú premisu, ktorá zahŕňa princípy morálneho kozmopolitizmu (princíp negatívnej morálnej povinnosti a univerzálnej perspektívy). Zdôvodnenie morálneho kozmopolitizmu obsahuje aj metodologický postup, na základe ktorého možno nejaký čin označit' za viac alebo menej užitočný - tzv. princíp maximalizácie úžitku. Hlavným dôvodom tohto zamerania je naše presvedčenie, že túto filozofickú líniu argumentácie súčasní efektívni altruisti prebrali, ${ }^{3}$ pričom ju rozšírili

\footnotetext{
${ }^{2}$ Pojem použil T. Ord (2014, s. 183).

${ }^{3}$ Napríklad W. MacAskill (2015) a Toby Ord, ktorí sa tiež inšpirovali prácami P. Singera a T. Poggeho (Gill, 2013).
} 
o empirické, racionalistické či prospechárske princípy, prostredníctvom ktorých sa pokúšajú posúdit' možnosti ochrany l'udských práv v najväčšmi zanedbávaných a kritických oblastiach. ${ }^{4}$ Tento prístup napovedá už aj sám názov: altruizmus nie je nejakým nezodpovedným, nezmyselným emocionálnym obetovaním pre druhých, ale je jednoduchou snahou zlepšit životy druhých. Efektívnost' zaist'uje, aby altruistická pomoc bola „chladnou“, optimalizovanou, aby pomoc zo zdrojov altruistických subjektov bola rozumná.

\subsection{Tri pozície efektívneho altruizmu, signifikantné pre l'udské práva}

Na posúdenie toho, či konkrétny problém je viac alebo menej vypuklý, používajú autori efektívneho altruizmu tzv. idealizovaný etický koncept. Východiskom tohto idealizovaného etického konceptu sú tri základné komponenty:

(1) Epistemologické: stupeň vierohodnosti, presvedčenia, charakter postojov, dôvera (označovaná tiež ako morálna istota) ${ }^{5}$ či dostatočné dôkazy o možných dôsledkoch intervencií racionálnych subjektov. Tieto nástroje umožňujú racionálnym subjektom pochopit', ktoré smerovanie je rozhodujúce v procese praktického rozhodovania a ktoré z intervencií sú najúčinnejšie pri ochrane l'udských práv. Napríklad stupeň dôvery a presvedčenie racionálneho subjektu pri porovnaní dvoch odlišných intervencií môžu byt' odlišné na základe empirických dôkazov; je jednoduché povedat', že istá forma antimalarickej liečby je účinnejšia ako druhá, ale je ovel’a náročnejšie uvažovat' medzi intervenciami, ktoré sú neporovnatel'né. Pre efektívnych altruistov je dôležité, aby sme o týchto epistemologických otázkach hovorili, pretože tým si pomáhajúci subjekt otvára cestu k pochopeniu rozumných spôsobov poznávania vhodných intervencií. Zároveň treba dodat', že práve tieto idealizované koncepty efektívni altruisti používajú pri praktickom rozhodovaní. To znamená, že obsažnost' ludských práv je závislá od normatívnych princípov a empirickej neistoty (MacAskill, 2018), a to vzhl'adom na naše presvedčenia a zámery efektívne maximalizovat' úžitok.

(2) Etické: efektívni altruisti sa zvyčajne opierajú o istý druh teórie dobra a teórie morálne správneho konania, ktorých povaha môže mat' metaetický charakter (spor medzi teoretikmi naturalizmu a nenaturalizmu $)^{6}$ alebo morálnych teórií - tzv. morálnych pravidiel. Napríklad Toby Ord (2015) argumentuje v prospech tvrdenia, že celé naše

\footnotetext{
${ }^{4}$ Základné kontúry efektívneho altruizmu položili W. MacAskill a študent filozofie v Oxforde T. Ord. V súčasnosti má efektívny altruizmus svojich obhajcov v radoch analytických oxfordských filozofov a filozofiek (napr. Hilary Greavesová).

${ }^{5}$ Vo filozofii Descarta a Leibniza sa tiež stretneme s pojmom morálnej istoty a pravdepodobnosti (Rey, 2018).

${ }^{6} \mathrm{~K}$ filozofickým aspektom naturalizmu a nonnaturalizmu vo vzt’ahu racionality a morálky pozri viac Pavlovkin $(2018,294-304)$.
} 
morálne konanie a morálne dobro sú determinované morálnymi výmenami: sofistikované ekonomické prístupy na dosiahnutie zisku sú prítomné aj pri morálnej výmene, kde by sme mohli hovorit' o ekvivalentoch morálnej meny, morálneho vyjednávania či morálnej fúzii. V rámci morálnej výmeny nezáleží na tom, aby sme sa zaujímali o zložité filozofické zdôvodnenia l'udských práv, pretože väčší zmysel má, ked’ sa budeme pýtat' na najefektívnejšie metódy posilnenia ich ochrany. Racionálny spôsob argumentácie obsahuje teda aj predpoklad špecifickej morálnej zodpovednosti, ktorú možno napadnút tvrdením, že je neprípustné, aby sme uprednostňovali záujmy jednej osoby (alebo skupiny) pred druhou. MacAskill na túto kritiku poznamenáva, že tento pohl'ad nemôže byt' správny. Potom by sme totiž nemohli povedat', že prispiet' niekomu na dezert prináša väčší úžitok ako zachránit’ niekomu život. Napokon, efektívni_altruisti uznávajú, že akékol'vek porovnávanie konkrétnych l'udských činov musí vychádzat' z nasledujúcej otázky: Pre kol'ko l'udí to je prospešné a do akej miery? Teda takéto etické zdôvodnenie l'udských práv sa vzt’ahuje na význam l'udských záujmov - teda substanciálne chápanie blaha alebo dobrého života.

(3) Teórie rozhodovania: zväčša tieto teórie slúžia na posúdenie a porovnanie očakávanej užitočnosti rôznych činov z hl’adiska pravdepodobnosti možných výsledkov. Teórie rozhodovania sa zvyčajne používajú na identifikáciu jedného alebo viacerých krokov, ktoré maximalizujú očakávanú užitočnost', pričom využívajú matematické, ekonomické alebo štatistické metódy. Napríklad predstavitelia efektívneho altruizmu využivajú ekonomické teórie a nástroje ako numerické úžitkové funkcie, metódy interpersonálnych komparatívnych meraní, teóriu maximalizácie očakávanej hodnoty alebo prostredníctvom ekonomických ukazovatel'ov poukazujú aj na nerovnomerné rozloženie zdrojov, globálno-politické a ekonomické pravidlá, ktoré determinujú charakter globálnej chudoby (určujúce spôsoby využívania daných zdrojov, znášanie nákladov a redistribúciu prospechu), či na rozhodovanie a konanie globálno-politických a ekonomických aktérov. ${ }^{7}$

Zhrňme si to. Efektívny altruizmus sa snaži byt' striktne vedecký či racionalistický (napríklad využívaním teórií rozhodovania), ale aj idealistický. To značí, že l'udské práva sú vymedzené (bez toho, aby bolo o nich explicitne hovorené) na základe činov, ktoré sú najefektívnejšie, najprospešnejšie, tie, ktoré sú vo všeobecnosti najviac zanedbávané, pri ktorých rozdiely medzi počiatkom a prípadnými zmenami sú vel'ké. Preto by sa nemali l'udské práva interpretovat' v žiadnom deontologickom alebo kontraktualistickom zmysle. Tieto metafyzické východiská teda nemajú len teoreticko-metodologický význam, v skutočnosti predstavujú aj nástroje na určenie obsahu a rozsahu blaha osôb, ktoré žijú v extrémnej chudobe. Najviditel'nejšie je to v prácach W. MacAskilla

\footnotetext{
${ }^{7}$ Singer $(2015,120$ - 121) sa pokúša aplikovat' ekonomické nástroje na porovnávanie rôznych druhov výhod pri posudzovaní toho, do akej miery si l’udia vážia určité stavy.
} 
a T. Orda, ktoré sa podl’a nás zameriavajú najmä na tretiu Singerovu premisu - teda ako možno nájst' najvhodnejšiu, respektíve najefektívnejšiu charitu. V štúdii sa tejto rovine primárne nevenujeme, hoci implicitne úzko súvisí s druhou, ktorej sa budeme venovat' v nasledujúcich častiach.

\subsection{Morálny kozmopolitizmus Singera}

Práce Singera sú známe najmä v oblasti praktickej etiky, ktorej nezanedbatel'nou súčast'ou je aj problematika l’udských práv v kontexte chudoby v rozvojových krajinách. A hoci sa Singer nikdy explicitne nevyjadruje o l'udských právach, napriek tomu takmer vo všetkých svojich známych dielach prezentuje názory, ktorými poukazuje na l'udské práva prostredníctvom perspektívy tých, ktorí ich priamo či nepriamo môžu chránit'. To mu umožňuje zmenit' zásadné etické princípy, podl'a ktorých by sa naša západná civilizácia mala riadit'. Singer sa nepýta ani na obsah, ani na povahu l'udských práv. Zaujímajú ho primárne príčiny, ktoré spôsobujú obyvatel'om utrpenie, a možnosti ochrany l'udských práv. Tým problematiku l’udských práv spája $\mathrm{s}$ praktickou realizáciou - $\mathrm{s}$ morálnou povinnost'ou pomáhat’ tým, ktorí sa ocitli v extrémnej chudobe. Singer v tejto súvislosti ponúka niekol'ko dôvodov v prospech takto chápanej morálnej povinnosti.

V prvom rade poukazuje na nedokonalý charakter západnej modernej spoločnosti, ktorá prispieva $\mathrm{k}$ porušovaniu l'udských práv obyvatel'ov rozvojových krajín (Singer, 2016b, 51). Charakter l'udských práv sa v tomto zmysle nekončí len pri materiálnych potrebách, ktoré sú odnímané rozvojovým krajinám vd’aka politickým a hospodárskym medzinárodným pomerom, ale aj samotným správaním obyvatel’ov rozvinutého sveta - napríklad používaním automobilov s vyššou spotrebou (Singer, 2006, 18). ${ }^{8}$ Taktiež obyvatelia rozvinutého sveta aj svojím nepriamym správaním berú l'ahkovážne problém chudoby. Dôkazom tohto tvrdenia je luxusný spôsob života (Singer, 2016a, 34). Singer týmto negatívnym opisom správanie obyvatel’ov západného sveta nepriamo akceptuje, pretože kritikou sa ich pokúša oslovit', aby racionálne zvážili a vysvetlili svoje nepodložené a mylné názory na základné etické princípy.

Prehodnotenie základných morálnych princípov tkvie aj v odmietnutí všeobecne uznávaného princípu, podla ktorého naše morálne povinnosti voči rodine a blízkym priatel’om sú pre nás záväznejšie a náročnejšie ako naše morálne záväzky voči tým, ktorí sú od nás psychologicky či fyzicky vzdialení. Tieto morálne intuície sú len pocity a tendencie, ktoré majú hodnotu prežitia, nič viac (Singer, 2006, 138). Sám základ pre-

\footnotetext{
${ }^{8}$ Pozri tiež St’ahel $(2015$, 9; 2018, 1 - 13) a k environmentálnemu princípu zodpovednosti pozri Smolková $(2018,731$ - 741). K téze o modernom subjekte spojeného s ekologickými katastrofami pozri aj Keck $(2017,32)$.
} 
ferenčného zaobchádzania s našimi blízkymi je chybný a svojvol'ný. Preto Singer odmieta, aby sa ochrana l'udských práv obmedzila na oblast' rodinných prahov a hraníc národných štátov (Singer, 2006, 127). Dôvodom tohto záveru je presvedčenie, že naše psychologické predispozície sú nepostačujúce. Napokon, ako aj sám píše: „Vel’a z nášho správania je založené na vel'mi rýchlych, inštinktívnych, emocionálne založených odpovediach. Aj ked' sme schopní rozhodnút' sa, čo robit' na základe racionálnych myšlienkových procesov, takéto rozhodnutia sa často ukážu ako menej silné ako naše inštinktívne pocity. “9 $\mathrm{Z}$ tohto pohl'adu podl’a Singera morálne predpisy nemôžu uvádzat' fakty alebo dokonca obmedzovat' morálne predpisy na základe poznatkov o nedokonalom svete. Inak povedané, morálne predpisy majú vyjadrovat' morálne presvedčenie a sú vyslovované, aby vyjavili pravdu o našich povinnostiach a dôvodoch.

Z toho, čo bolo doposial' naznačené, vyplýva, že Singer obhajuje tvrdenie, podl'a ktorého naše normatívne dôvody slúžia na opis toho, čo by sme mali robit'. Tieto normatívne dôvody nesmú byt' založené na túžbach či osobných preferenciách, ale na univerzálnej perspektíve (Singer, 2009, 47 - 49), čo však neznamená, že tieto všeobecné predpisy nie sú aplikovatel'né v praktickom konaní. Práve naopak, aplikovanie všeobecného predpisu na konkrétny čin musí byt' konfrontované s normatívnymi dôvodmi, aby sme zistili, či môžeme akceptovat' tento predpis vo všetkých situáciách, reálnych alebo hypotetických, ktoré sú vo svojich univerzálnych znakoch podobné.

Pokial' ide o obsah normatívneho dôvodu, ako sme už aj naznačili, ten je podmieňovaný univerzálnou perspektívou, podl’a ktorej sa záujmy ostatných berú do úvahy rovnako ako naše vlastné. Jadrom tejto myšlienky morálneho kozmopolitizmu je teda to, že každá l'udská bytost' má rovnakú morálnu hodnotu a rovnaká morálna hodnota vytvára určité morálne povinnosti, ktoré majú univerzálny dosah. Naše povinnosti voči ostatným sa berú rovnako ako voči našim blízkym. ${ }^{10}$ Singer napokon obhajuje názor, že každý sa usiluje zmiernit' bolest' druhých bez ohl'adu na trpiaceho. Takýto nezávislý a nestranný dôvod nie je viazaný na žiadne preferencie človeka (Singer, 1993, 317).

Filozofické zdôvodnenia l'udských práv morálneho kozmopolitizmu možno doložit' aj na základe neurovedeckých výskumov. Lazari-Radeková a Singer $(2017,40)$ sa odvolávajú na výskum J. Greeneho (2013, kap. 4 a 5), podl'a ktorého l'udské morálne uvažovanie má dva hlavné procesy: spontánny a korigovaný. Spontánne morálne uvažovanie sa vyvíjalo počas niekol'kých tisícročí a slúži nám najmä pri bežných emocionálnych zrýchlených reakciách, zatial' čo korigované uvažovanie jasne

\footnotetext{
${ }^{9}$ Vychádzame z článkov uverejnených v knihe Singer (2016b).

${ }^{10} \mathrm{~K}$ intersubjektívnemu pochopeniu univerzálnych l’udských práv v Tugendhatovej antropológii pozri Muránsky $(2017,808)$ a k antropologickej kritike l'udskej prirodzenosti pozri Zarka (2018, $783-785)$.
} 
ukázalo, že sa snažíme konat' racionálne, aby sme zabezpečili najvyššiu možnú úroveň úžitku. Na základe tohto výskumu obhajujú myšlienku, že aj z tohto dôvodu treba upravit' či riadit' l'udskú prirodzenost', aby altruistické správanie nebolo ovplyvnené príslušnost'ou k skupine (Bruneau, Dufour, et al., 2012). ${ }^{11}$ Steven Pinker (2012, kap. 9) v tomto duchu navrhuje, aby sa na podporu zmeny l'udskej prirodzenosti rozprašoval do vzduchu oxytocín, ktorý stimuluje empatické procesy v l’udskom mozgu, čo by urýchlilo formovanie globálneho empatického vedomia. Efektívni altruisti sa odvolávajú aj na výskumy (Lazari-Radek \& Singer 2017, 111), ktoré potvrdzujú hypotézu, že altruistická orientácia na druhých je pravdepodobne najspol’ahlivejší spôsob, ako môže altruista nadobudnút' osobné blaho (Thoits \& Hewitt, 2001). Druhá rovina naturalizmu sa týka prijímatel'ov pomoci, pretože skupina prijímatel'ov je závislá od empiricky potvrdeného úžitku (tzv. minimalizácie počtu umierajúcich, maximalizácie št'astia, efektívneho vynakladania prostriedkov, cenovej efektívnosti intervencií a iné). Charakteristika prijímatel’ov nie je primárnou záležitost'ou, ked’že efektívny altruista sleduje účinky žiaducich alebo nežiaducich dôsledkov. Lazari-Radek a Singer sa vo Velmi krátkom úvode do utilitarizmu $(2017,116)$ hlásia k najjednoduchšej verzii utilitarizmu - teda $\mathrm{k}$ maximalizácii št’astia.

Morálny kozmopolitizmus prezentovaný v Singerových prácach sa teda zameriava na obhajobu negatívnej morálnej povinnosti, ktorá vychádza z klasickej utilitaristickej myšlienky nestrannosti a maximalizácie úžitku. $\mathrm{V}$ tomto zmysle sa utilitaristi snažia maximalizovat' úžitok za rôznych podmienok, pričom konkrétne činy, ktoré budú za týchto okolností správne alebo nesprávne, sa budú vel'mi líšit' od konkrétnych skutkov, ktoré sú pre nás správne alebo nesprávne z pohl'adu reflexívnej morálky. ${ }^{12}$ Jednoducho povedané, pre utilitaristu je klúčové maximalizovat' úžitok, pretože žiadna iná morálka (okrem utilitarizmu) nemôže obhájit' myšlienku maximalizácie úžitku. ${ }^{13}$ Takéto morálne zdôvodnenie efektívneho altruizmu okrem filozoficko-morálnych a metafyzických rovín zahŕňa aj inštitucionálno-politickú, ktorú priblížime v nasledujúcej časti.

${ }^{11}$ Efektívni altruisti odmietajú tradičné teórie altruizmu - teóriu prosociálneho správania, recipročný altruizmus či evolučný altruizmus, pretože všetky interpretujú altruistické správanie ako čin vel'korysosti alebo lásky.

${ }^{12} \mathrm{~V}$ utilitaristickej tradícii existujú dva hlavné konprehenzívne prístupy: utilitarizmus činu a utilitarizmus pravidla. Utilitarizmus činu posudzuje každý jednotlivý čin z hl’adiska jeho dôsledkov. Utilitarizmus pravidla posudzuje činy na základe toho, či sú v súlade s podstatnými morálnymi pravidlami a či akceptovanie pravidla prináša najlepší výsledok. Efektívni altruisti spravidla obhajujú pozície utilitarizmu činu (Lazari-Radek a Singer, 2017, 91). Singera možno interpretovat' aj ako zástancu utilitarizmu pravidla $(2009,15)$. Okrem týchto podôb utilitarizmu existujú aj iné, pričom sa môžu navzájom radikálne líšit' v tom, čo je hodnotné, a teda aj z hladiska ich praktických dôsledkov. Štandardne ide o hedonizmus, preferenčný utilitarizmus, ale aj o rôzne negatívne podoby utilitarizmu.

${ }^{13} \mathrm{~K}$ problematike univerzálneho chápania l’udských práv pozri Sedová $(2018,319)$ a Palovičová (2017, $46-48)$. 


\subsection{Poggeho inštitucionálno-politické chápanie l’udských práv}

Efektívny altruizmus obsahuje metafyzické princípy, ktoré sa však usiluje aplikovat' do praxe, a to vrátane metacharitatívnych organizácií efektívneho altruizmu, charitatívnych organizácií ovplyvnených efektívnym altruizmom, blogov, konferencií, vedeckých prác a webových stránok s kariérnym poradenstvom. Jedným z praktických politických prístupov je aj inštitucionálno-politický rámec ludských práv Thomasa W. Poggeho, ktorý rozpracoval v diele Svetová chudoba a l'udské práva. ${ }^{14}$

Poggeho argumentácia sa značne podobá argumentácii Singera (2006), pretože v prvom rade sa opiera o štatistické fakty súvisiace s rozložením globálneho bohatstva, mierou chudoby či úmrtnosti. Na základe týchto poznatkov Pogge označuje globálnu chudobu za morálnu katastrofu (Pogge, 2002, 4), ktorú vo vel'kej miere spôsobujú aj občania západného sveta (napríklad obmedzovaním morálnych noriem zaistujúcich obživu a dôstojnost' tých najzranitel'nejších). ${ }^{15}$ Ako vidíme, politické zdôvodnenie ludských práv sa vo vel'kej miere zameriava na také globálne, hospodárske a politické znaky globálnej spravodlivosti, ktoré významne podporujú pretrvávanie závažnej chudoby, a z nich na medzinárodnej úrovni extrahuje konkrétne reformné politické opatrenia, ktoré majú ako svoju povinnost' uplatňovat' najmä obyvatelia západných krajín. V prvom rade Pogge vidí možnost' reformovat' medzinárodný systém tak, aby bol schopný zabezpečit' bezpečný prístup k objektom l’udských práv pre l’udí žijúcich v extrémnej chudobe, ${ }^{16}$ a to napríklad prostredníctvom väčšej rozptýlenosti vládnej autority jednotlivých štátov (Pogge, 2002, 178).

Negatívne formulovaná povinnost', ako sme ju načrtli v tvorbe Poggeho, nepredstavuje jediný filozofický prístup; vo filozofii sa môžeme stretnút' aj s pozitívnou morálnou povinnost'ou. Tá predkladá zdôvodnenia na zmiernenie nepriaznivých podmienok druhých. Efektívny altruizmus si kladie za svoju povinnost' pomáhat' pozitívne, pretože obyvatelia bohatých štátov môžu jednoducho zmiernit' podmienky chudobných. Rozdiel medzi negatívnou a pozitívnou povinnost'ou možno ukázat' na prostom príklade. Ak budeme nejakým spôsobom podporovat' globálny obchod, a ten poškodzuje chudobných, pravdepodobne budeme mat' negatívnu morálnu povinnost' zabránit' utrpeniu. Ak však darujeme finančné prostriedky na nadáciu proti malárii (AMF), pravdepodobne budeme mat' pozitívnu morálnu povinnost' (nie sme zodpovední za výskyt malárie, ale môžeme cítit' potrebu pomôct', pretože skrátka môžeme).

Podla nás efektívnym altruistom nezáleží primárne na rozdiele medzi negatívnymi a pozitívnymi povinnost’ami: jednoducho máme povinnost' maximalizovat' dobro a zabránit' maximálnemu množstvu zla bez ohl'adu na našu zodpovednost' a povinnost'.

\footnotetext{
${ }^{14}$ Pozri tiež Marcinková (2012).

${ }^{15}$ Pozri tiež Hulme (2016).

${ }^{16}$ Pozri tiež Singer (2016a, kap. 2).
} 
Iste, je t’ažké rozlíšit pozitívne a negatívne povinnosti v oblasti medzinárodnej pomoci, ale zdá sa nám, že vo väčšine prípadov efektívni altruisti argumentujú v medziach negatívnej povinnosti. Napríklad Pogge pri inštitucionálnej ochrane l’udských práv argumentuje v rámci negatívnej povinnosti v normatívnom jazyku: „'Ludské právo $\mathrm{X}$ vám dáva morálny nárok voči všetkým ostatným, že každý z nich (najmä obyvatelia zo západných spoločnosti) spraví, čo je v jeho moci, aby zaistil, aby ste mali X“ (Pogge, $2005,64)$. Negatívnu povinnost' možno doložit' v prípade Singera $(2009,17)$ aj na prípade topiaceho sa diet’at'a v rybníku. ${ }^{17}$

Hoci efektívni altruisti implicitne uznávajú negatívnu povinnost', napriek tomu ju neberú do úvahy. Efektívni altruisti sa zamýšlajú nad maximalizáciou dobra, avšak nikde sa nezaoberajú mierou individuálnej zodpovednosti a rozsahom škôd občanov západných krajín, štátov či medzinárodných inštitúcií. Tento problém sa objavuje aj v Poggeho práci, pretože spája problémy morálnej zodpovednosti s politicko-právnou funkciou l'udských práv. Výhodou tohto prístupu je, že zohl'adňuje a zdôrazňuje inštitucionálne bariéry, ktoré môžu obmedzovat' realizáciu l’udských práv, no na druhej strane nie je úplne jasné, ktorí konkrétni jednotlivci, konkrétne štáty či medzinárodné inštitúcie a v akom rozsahu majú povinnosti identické s l’udskými právami.

\section{Vybrané kritické námietky voči chápaniu l’udských práv v efektívnom altruizme 2.1 Transformácia tradičných morálnych základov}

Prvý problém pri chápaní l’udských práv tkvie v Singerovej téze, že by sme mali radikálne transformovat' našu morálku, a to tak, aby v jej základoch nebol konštituovaný princíp preferenčného zaobchádzania s našimi blízkymi. Týmto postupom Singer uznáva, že v základoch našej morálky sú síce isté sociálne poznatky o našom správaní, zároveň však odmieta, aby na týchto základoch bola postavená morálka. Problémom tohto postupu je, že spochybňuje morálnu intuíciu len na základe presvedčenia, že sociobiologické fakty principiálne dokazujú nesprávnost' základov morálky.

Ak sa Singer pokúša preukázat', že naše morálne intuície v tejto oblasti sú nesprávne, nestačí argumentovat', že uvedené správanie neprispieva k najväčšiemu št’astiu najväčšieho počtu l'udí. Okrem tohto musí dokázat', že psychologické príbuzenské väzby - akými sú bezpochyby osobitá láska matky, otca, súrodencov, detí - sú zvrátené. Samozrejme, takáto argumentácia by bola v príkrom rozpore so sociálnou praxou. ${ }^{18}$ Avšak Singer sa o to pokúša, ked' používa psychologické fakty na zdôvodnenie normatívneho postupu, v ktorom príbuzenská preferencia neprospieva iným. Asi v tejto súvislosti netreba zdôrazňovat', že normatívne postupy nemusia principiálne vychádzat'

\footnotetext{
${ }^{17}$ Pogge je skôr deontológ, zatial’ čo väčšina efektívnych altruistov sú konzekvencialisti.

${ }^{18}$ V štúdii Koubová a Urban $(2018,719)$ rovnako zdôraznujú, že aj etika starostlivosti vychádza z predpokladu, že každá l’udská bytost' je podstatne závislá od vzt’ahov s inými osobami.
} 
zo skutočnosti - teda normatívnost' nie je redukovatel'ná na fakty. To je aj dôvod, prečo sú hodnoty a fakty tak často v konflikte, čo sa prejavuje aj v kozmopolitnom Singerovom chápaní l'udských práv.

\subsection{Epistemologické limity}

Ak sa altruistický subjekt pokúša uplatnit’ morálne kódy alebo morálne princípy maximalizácie úžitku, musí sa vysporiadat's námietkou, podl'a ktorej l'udské bytosti nikdy nevedia, aký zákon alebo systém pravidiel alebo univerzálnych postupov by bol definitívne optimálny. ${ }^{19}$ Takže ak efektívny altruizmus vyžaduje, aby sme si vybrali optimálny čin alebo konali v súlade s optimálnym súborom pravidiel alebo univerzálnych postupov, je dost' možné, že zlyháme a budeme sa ich musiet' vzdat'. Samozrejme, táto námietka je v literatúre pomerne živá a vyvoláva vo filozofických konzekvencialistických kruhoch rôzne reakcie. ${ }^{20}$

Konzekvencializmus túto námietku rieši dvoma líniami argumentácie: bud' subjektivistickou, pri ktorej celé t’ažisko problému poznania a morálnej zodpovednosti je na epistemickom subjekte; alebo objektivistickom, v ktorom rozhodujúcu úlohu poznania určuje autorita. Subjektivistický pohl'ad požaduje iba konanie, ktoré je v súlade s pravidlami alebo sociálnymi praktikami, ktorým epistemický subjekt dôveruje (je oprávnený verit’ im), že sú optimálne. Ako píše T. W. Pogge: „Morálne údaje (naša intuícia alebo najhlbšie presvedčenie) sú to, čím sú, a koherentnost’ je v každom prípade v očiach pozorovatel'a“" $(2002,101)$. Problémom tohto individuálneho prístupu je, že vhodnost' alebo efektívnost' daných činov nemôže pochádzat' len z individuálneho rozhodovania, pretože takéto subjektívne prístupy nie sú adekvátne vzhl'adom na zdôvodnenie všeobecného práva, ked’že vedú k subjektívne premenlivým požiadavkám. Z tohto dôvodu altruistický subjekt by mal brat' ohl'ad aj na kolektívne (resp. inštitucionálne) rozhodovanie. ${ }^{21}$

Na prvý pohl'ad argumentácia subjektivizmu vyzerá ako základ pre argumentáciu proti objektivizmu. V skutočnosti snaha nachádzat' istotu v subjekte má pôvod v tvrdení objektivistov, že l'udský úsudok o tom, čo je dobré, nie je spol'ahlivý, a preto by sa mal opierat' o nejakú autoritu (v prípade efektívneho altruizmu autoritou môže byt' filantropická organizácia, ktorá identifikuje najefektívnejšie intervenčné spôsoby). ${ }^{22} \mathrm{Ar}$ gumentovat' proti objektivistickým prístupom možno na základe obáv z možného zneužitia a potenciálnych negatívnych vedl'ajších účinkov, ktoré sú reálne a relevantné

\footnotetext{
${ }^{19}$ Pozri viac prácu napríklad Brandta (1992) a článok MacAskilla (2016).

${ }^{20}$ Podl’a konzekvencialistov kritika antiracionalistov je nedostatočná, ked’že racionálny kalkul založený na výhodách a nevýhodách je prítomný aj pri uznaní rešpektu (Pettit, 1994).

${ }^{21}$ Túto námietku možno vzniest' napríklad voči MacAskillovej komparatívno-subjektívnej teórii (2016).

22 Tento problém bol reálne pomenovaný v diskusii na stránkach efektívneho altruizmu (Drescher, 2017).
} 
pre akýkol'vek pokus o odôvodnenie legálneho zasahovania autority do rozhodovania subjektu. Takáto argumentácia spätne vedie ku kognitívnym charakteristikám subjektu. Ponechat' celú t’archu problému na subjekte je podl'a nás nesprávne. Totiž podstata problému podl'a nás tkvie v tom, že všetky pravidlá teoretického rozhodovania mlčky predpokladajú porovnatel'nost' individuálnych predstáv o výslednom prospechu a úžitku daného konania, čo však v rovine empírie nemožno realizovat'. Preto ochrana l'udských práv bude vecou náhody a bude závisiet' od empirickej reality alebo hypotetického modelovania.

\subsection{Morálna, politická a právna normatívnost' l’udských práv}

Z doposial' načrtnutých úvah vyplýva, že sme sa sústredili na psychologicko-morálnu a epistemicko-subjektivistickú rovinu, ktorá predstavuje rozhodujúci rámec pre zdôvodnenie tých l’udských práv, ktoré sú podl'a efektívneho altruizmu najväčšmi zanedbávané. Do týchto rámcov treba zahrnút' aj iné, ktoré sa týkajú výlučne morálneho, politického či právneho zdôvodnenia l'udských práv. Zatial' čo Singerov kozmopolitizmus sa sústred'uje na psychologické a morálne zdôvodnenie, Poggeho teoretické východiská sa zameriavajú na politickú normatívnost' l'udských práv, pričom obidva prístupy majú svoje nedostatky.

Singerov morálny kozmopolitizmus sa zaciel'uje na príliš špecifický opis a hodnotenie niektorých situácií, ktoré slúžia ako normatívne stanovisko k morálnemu odsúdeniu občanov, štátov a vlád, ked' konajú zle vo vzt'ahu k obyvatel'om tretieho sveta. Zároveň morálne chápanie l'udských práv zdôvodňuje niektoré medzinárodné činy (podpísanie, ratifikáciu a zmenu a doplnenie medzinárodných zmlúv), ale aj ospravedlňuje celý rad medzinárodných zásahov. Problémom morálneho zdôvodnenia l'udských práv je to, že odkazuje na prax v oblasti l'udských práv nanajvýš ako na skúšku svojho teoretického návrhu. To znamená, že morálna kategória „vnímajúcej bytosti““ zachytáva zmysel, v ktorom sú l’udské práva základnými morálnymi požiadavkami, pričom jej platnost' nie je závislá od podmienených empirických faktov. To je aj príčinou, prečo toto stanovisko nie je schopné obsiahnut' niektoré nároky a požiadavky v rámci konkrétnych kontextov.

Pokial' ide o politické zdôvodnenie l'udských práv, to vychádza z predpokladu, že l'udské práva slúžia ako praktické zdôvodnenia konkrétnych politických rozhodnutí a činov. V Poggeho prístupe povaha, štruktúra a obsah l’udských práv sú plne závislé od globálnej politickej praxe - teda medzinárodného systému či jeho aktérov. Preto je celá argumentácia postavená na radikálnej premene globálneho systému. Problémom tohto prístupu je, že neberie do úvahy právny rámec, ktorého súčast’ou nie sú len medzinárodné inštitúcie, ale aj súdne orgány jednotlivých štátov a vnútroštátna právna prax. Kritici efektívneho altruizmu v tomto zmysle zdôrazňujú, že pri riešení globálnej 
chudoby treba vykonat' konkrétne vnútroštátne politické, inštitucionálne či právne reformy (Lichtenberg, 2015). Východiskom tejto argumentácie je téza, že inštitucionálne reformy - akými sú napríklad demokratizačné reformy v oblasti individuálnej a politickej slobody - ovplyvňujú znižovanie chudoby v konkrétnych štátoch (Sen, 2009, 342; Halperin et al., 2005). ${ }^{23}$ Toto politické normatívne zdôvodnenie určuje, ktoré právne nástroje by mohli byt' uplatnené pri úvahách o blahu, ako napríklad koncepcia spôsobilosti (Sen, 1993, 31). ${ }^{24}$

Morálne a politické normatívne zdôvodnenie l'udských práv podl’a nás vo všeobecnosti takmer vôbec nereflektuje právny rozmer l'udských práv. Politické zdôvodnenia dospievajú k záveru, že medzinárodné inštitúcie nie sú schopné potrestat' porušovatel'ov práv rozvojových krajín, no zároveň akosi zabúdajú na právny princíp subsidiarity, z ktorého jednoznačne vyplýva, že právny a súdny rozmer l’udských práv sa vykonáva najmä na úrovni vnútorných praktík štátu. Tieto praktiky vo vel'kej miere určujú a identifikujú práva, vymedzujú charakteristiky konkrétnych držitel'ov práv či vymedzujú pôvod týchto práv. Z tohto dôvodu politické a morálne zdôvodnenia l'udských práv síce legitimizujú l’udské práva na medzinárodnej úrovni, ale len vel’mi okrajovo reflektujú miestnu právnu a súdnu prax v konkrétnych štátoch, ktorých sa týka chudoba. Navyše, ako sme už aj naznačili, z morálneho aj politického zdôvodnenia l'udských práv nie je celkom jasné, kto a v akom rozsahu spôsobuje škody rozvojovým krajinám a kto a v akom rozsahu má uskutočnit’ konkrétne politické opatrenia.

\section{Záver}

Hoci vo filozofii efektívneho altruizmu sa priamo nestretneme s explicitným problematizovaním l'udských práv, v štúdii sme sa pokúsili načrtnút implicitné filozofické východiská, ktoré súvisia so zdôvodnením l’udských práv. V prvej časti sme poukázali na Singerov morálny kozmopolitizmus, pričom v druhej časti sme zdôraznili, že prísne presadenie morálneho diskurzu l'udských práv je nepostačujúce, ked’že je v rozpore so sociálnou praxou. Okrem morálnej roviny sme sa sústredili na politickú normatívnost' l'udských práv u Poggeho, ktorá nedostatočne objasňuje, ktoré subjekty by mali prebrat' zodpovednost' za nevyhovujúce podmienky občanov v rozvojových krajinách. Napokon sme dospeli k záveru, že morálne, a taktiež politické zdôvodnenia l'udských práv len vel'mi okrajovo reflektujú ich právnu rovinu. Tým, že oba prístupy nezohl'adňujú situovanost' práv (spôsob, akým sa uplatňujú, a ich interpretáciu

\footnotetext{
${ }^{23}$ Podl’a Singera demokratické vlády (legitimizované väčšinou) nie sú garanciou dodržiavania l'udských práv, ale zároveň pripomína, že otvorené procesy môžu zabránit' ich prípadnému porušovaniu (Singer, 2006, 118 - 119). K súčasnej povahe demokracie pozri taktiež Šaradín (2017, 306 - 311).

${ }^{24}$ G. Schweiger a G. Graf (2015) sa pokúšajú aplikovat' prístup spôsobilosti na problém chudoby v kontexte globálnej spravodlivosti a medzinárodnej politickej teórie (pozri kap. 4).
} 
v konkrétnej sociálnej praxi), neposkytujú konkrétne riešenia. Obom prístupom by pomohlo, keby sa nesústredili len na zdôvodnenie univerzálnej spravodlivosti, nestrannosti či psychologické predispozície altruistických subjektov, ale väčšmi sa venovali kontextovým procesom zdôvodňovania l'udských práv v konkrétnej sociálnej praxi.

\section{Literatúra}

BRANDT, R. B. (1992): Morality, Utilitarianism, and Rights. New York: Cambridge University Press.

BRUNEAU, E. G., DUFOUR, N., SAXE, R. (2012): Social cognition in members of conflict groups: behavioural and neural responses in Arabs, Israelis and South Americans to each other's misfortunes. Philosophical Transactions Biological Sciences, 367 (1589), 717 730. [https://royalsocietypublishing.org/doi/10.1098/rstb.2011.0293]

DENEULIN, S., CROCKER D. (2006): Capability and Democracy. HDCA Introductory Briefing Note. [online]. Human Development \& Capability Association. Dostupné na: https://hd-ca.org/publications/capability-and-democracy (Navštívené 13. 1. 2019).

DRESCHER, D. (2017): Cause Area: Human Rights in North Korea. [online]. Effective Altruism Forum. Dostupné na: http://effective-altruism.com/ea/1hm/cause_area_human_ rights_in_north_korea/ (Navštívené: 11. 1. 2019).

GILL, M. (2013): The man who gives away a third of his income. [online]. New Statesman. Dostupné na: https://www.newstatesman.com/business/2013/01/man-who-gives-awaythird-his-income (Navštívené: 11. 5. 2019).

GREENE, J. (2013): Moral Tribes: Emotion, Reason, and the Tap Between us and Them. New York: Penguin Press.

HALPERIN, M. H., SIEGLE, J. T., WEINSTEIN M. M. (2005): The Democracy Advantage: How Democracies Promote Prosperity and Peace. New York: Routledge.

HULME, D. (2016): Should Rich Nations Help the Poor? Cambridge: Polity.

KECK, F. (2017): Rozpúšt’anie subjektu a ekologická katastrofa u Leviho-Straussa. Filozofia, $72(1), 31-45$.

KOUBOVÁ, A., URBAN, P. (2018): Vztahové pojetí morální subjektivity mezi etikou péče a teorií hry Donalda Winnicotta. Filozofia, 73 (9), $717-730$.

LICHTENBERG, J. (2015): Peter Singer's Extremely Altruistic Heirs. [online]. The New Republic. Dostupné na: https://newrepublic.com/article/124690/peter-Singers-extremelyaltruistic-heirs (Navštívené: 11. 1. 2019).

LAZARI-RADEK, K., SINGER, P. (2017): Utilitarianism: A Very Short Introduction. Oxford: Oxford University Press.

MACASKILL, W. (2013): What Charity Navigator Gets Wrong About Effective Altruism. Stanford Social Innovation Review. Dostupné na: https://ssir.org/articles/entry/what_charity_navigator_gets_wrong_about_effective_altruism (Navštívené: 11. 5. 2019).

MACASKILL, W. (2015): Doing Good Better: Effective Altruism and a Radical New Way to Make a Difference. London: Guardian Faber Publishing.

MACASKILL, W. (2016): Normative Uncertainty as a Voting Problem. Mind, 125 (500). [https://doi.org/10.1093/ mind/fzv169] 
MACASKILL, W., ORD, T. (2018): Why Maximize Expected Choice-Worthiness? Noûs, 52 (1), $1-27$.

[https://doi.org/10.1111/nous.12264]

MARCINKOVÁ, H. (2012): Extrémna chudoba ako problém zanedbania negatívnych povinností globálnej spravodlivosti. Filozofia, 67 (8), 731 - 742.

MURÁNSKY, M. (2017): Neriešitel'ný problém univerzalizmu v Tugendhatovej antropológii. Filozofia, 72 (10), $800-812$.

ORD, T. (2014): Global poverty and the demands of morality. In: Perry, J. (eds.) God, the Good, and Utilitarianism: Perspectives on Peter Singer. New York: Cambridge university press, $177-191$.

ORD, T. 2015. Moral Trade. Ethics, 126 (1), 118 - 138.

PALOVIČOVÁ, Z. (2017): Ambivalentnost' l'udských práv a neurčitost' ich pojmu z pohl'adu filozofie. Bratislava: VEDA.

PAVLOVKIN, K. (2018): Vzt’ah racionality k morálke. Filozofia, 73 (4), 294 - 304.

PETIT, P. (1994): Consequentialism and moral psychology. International Journal of Philosophical Studies, 2 (1), 1 - 17.

PINKER, (2012): The Better Angels of Our Nature: Why Violence Has Declined. New York: Penguin Books.

POGGE, T. (2002): World Poverty and Human Rights. Cambridge: Polity Press.

POGGE, T. (2005): Severe Poverty as a Violation of Negatíve Duties (Reply to the Critics). Ethics and International Affairs, 19 (1), 55 - 83.

REY, A.-L. (2018): Morálna istota v Leibnizovej prírodnej filozofii. Filozofia, 73 (7), 520 528.

SEDOVÁ, T. (2018): Jánusovská tvár l'udských práv: medzi l’udskou dôstojnost'ou a právom mat' práva. Na margo troch kníh o problematike l’udských práv. Filozofia, 73 (4), 318 - 328.

SEN, A. (1993): Capability and Well-Being. In: Nussbaum M. and Sen, A. The Quality of Life. Oxford: Clarendon Press, $30-53$.

SEN, A. (2009): The Idea of Justice. Cambridge, Massachusetts: Belknap Press.

SCHWEIGER G., GRAF G. (2015): A Philosophical Examination of Social Justice and Child Poverty. Salzburg: Palgrave Macmillan.

SINGER, P. (1972): Famine, Affluence, and Morality. Philosophy and Public Affairs, 1 (1), $229-243$.

SINGER, P. (1993): Practical Ethics. Cambridge: Cambridge University Press.

SINGER, P. (2006): Jeden svet etika globalizácie. Bratislava: Vydavatel'stvo Spolku slovenských spisovatel'ov.

SINGER, P. (2009): The Life You Can Save: Acting Now to End World Poverty. New York: Random House.

SINGER, P. (2015): The Most Good You Can Do. How Effective Altruism Is Changing Ideas About Living Ethically. New Haven and London: Yale University.

SINGER, P. \& GATES, M. (2016a): Famine, Affluence, and Morality. Oxford: Oxford University Press.

SINGER, P. (2016b): Ethics in the Real World. 86 Brief Essays on Things that Matter. Princeton: University Press.

SMOLKOVÁ, E. (2018): K otázke vplyvu Hansa Jonasa na súčasnú etiku. Filozofia, 73 (9), $731-741$. 
SŤAHEL, R. (2015): Environmentálna zodpovednost' a environmentálna bezpečnost'. Filozofia, 70 (1), $1-12$.

SŤAHEL, R. (2018): Environmentalizmus ako politická filozofia pre 21. storočie. Filozofia, $73(1), 1-13$.

ŠARADÍN, P. (2017): Úvahy o současné demokracii. Filozofia, 72 (4), 306 - 311.

THOITS, P. A., HEWITT, L. N. (2001): Volunteer work and well-being. Journal of Health and Social Behavior, 42 (2), 115 - 131.

ZARKA Y. (2018): Má ešte pojem l'udská prirodzenost' zmysel? Filozofia, 73 (10), 777 - 789.

Príspevok vznikol ako súčast' grantového projektu VEGA 1/0132/17 Právo na nezávislý život a začlenenie do spoločnosti osôb s postihnutím z pohl'adu sociálnej a politickej filozofie.

Martin Foltin

Filozofický ústav SAV

Klemensova 19

81364 Bratislava 1,

Slovenská republika

e-mail: mart.foltin@gmail.com

ORCID ID: https://orcid.org/0000-0003-3981-7811 